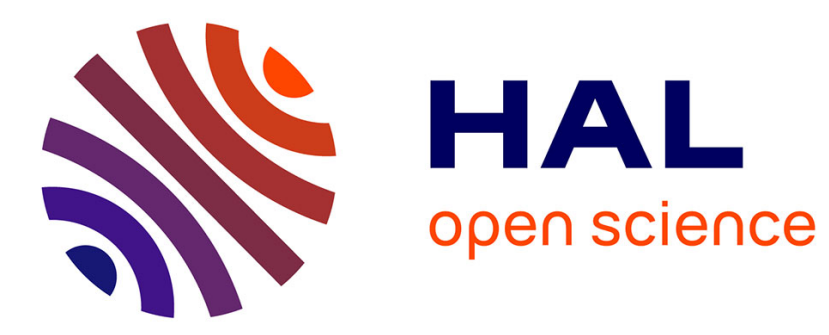

\title{
Lost in Transition: Ordeals of Passage of Palestinian Refugees in Lebanon \\ Nicolas Puig
}

\section{To cite this version:}

Nicolas Puig. Lost in Transition: Ordeals of Passage of Palestinian Refugees in Lebanon. Mediterranean Politics, 2013, 18 (3), pp.394-410. 10.1080/13629395.2013.834565 . hal-01323856

\section{HAL Id: hal-01323856 https://hal.science/hal-01323856}

Submitted on 1 Jun 2016

HAL is a multi-disciplinary open access archive for the deposit and dissemination of scientific research documents, whether they are published or not. The documents may come from teaching and research institutions in France or abroad, or from public or private research centers.
L'archive ouverte pluridisciplinaire HAL, est destinée au dépôt et à la diffusion de documents scientifiques de niveau recherche, publiés ou non, émanant des établissements d'enseignement et de recherche français ou étrangers, des laboratoires publics ou privés. 


\title{
Lost in Transition: Ordeals of Passage of Palestinian Refugees in Lebanon
}

\author{
NICOLAS PUIG \\ URMIS (IRD, Université Paris-Diderot et UNSA) and CEMAM, UIR Mémoire, University St Joseph, \\ Beirut Lebanon
}

ABSTRACT Working on the practices of mobility of Palestinian refugees in Lebanon, the research showed up the recurrence and, seemingly, the social importance given to the numerous situations of crossing borders and boundaries that the refugees have to go through. In these moments, some forms of specific social exchange take place in the folds (plis/replis/ creux) of mobilities. This research labels them transactions: the term contains the two main elements that define the situation: transition (passages) and interaction (social exchanges). Starting with refugees from the Palestinian Nahr al-Bered camp in Lebanon, it describes experiences of passage ranging from the local to the transnational scales.

I went to Athena, I mean, what can I say ... Like a prison. It was like a huge prison. Athena was like a big prison. Very anarchical, but you can't work, you don't know anybody to work with. (Baha, Nahr Al-Bared camp, Lebanon, 2011)

My plane was at, let's say, eleven in the morning ... I landed in Lebanon around one o'clock. I thought: 'oh my God, it is the first time I take a plane'. I thought: 'my God, all this suffering that I had after leaving, all this ...' We were about to die when we arrived in Greece. And at the end in less than two hours you are in Lebanon. Seriously, it is disquieting, look: all this suffering for this! (Najdé, Nahr Al-Bared camp, Lebanon, 2011)

\section{Introduction}

This article discusses and analyses the relational dimensions of border crossings by Palestinians from Lebanon in the course of their mobilities. This includes borders of different natures and different scales, such as national or spatial borders, as well as social and cultural boundaries.

Early research on Palestinian refugees in Lebanon tended to focus on the history of the group and on the social and symbolic role of the camps, seen as its emblematic

Correspondence Address: Nicolas Puig, Université Paris-Diderot, Paris 7 / URMIS, Case 7027, 75205

Paris Cedex 13. Email: nicolas.puig@ird.fr 
space. Priority was given to the analysis of the refugee community as a whole and to the description of its settlement in Lebanon. Social and oral histories shed light on different aspects of the progressive structuring of the community and on the different ordeals it had to overcome to create to create 'a sense of place, identity, and meanings in new places' (Peteet, 2005, p. 1; see Sayigh, 1979, 1994, 2006).

The legal and political reception of Palestinians in Lebanon in 1948, and the role of the $\mathrm{Nakba}^{1}$ in the construction of a collective narrative, were described by Sfeir (2008), who added a new facet to existing research on Palestinian refugees in Lebanon.

Anthropologists have given priority to situated studies by anchoring their fieldwork in a camp or a gathering taken as an anthropological site: Chatila, Burj alBarajné, Jal al-Bahr and Nahr al-Bared. ${ }^{2}$ Yet multi-scalar research that takes into account the fluidity of scale remains sparse.

Transnational dimensions are not completely absent from these analyses. Reconfigurations of intimacy by (social, cultural) dynamics of the diaspora, or questions of transnational families, for example, have been discussed (see Perdigon, 2010). ${ }^{3}$ I would add some remarks on the different ways in which the global situation of Palestinian refugees refracts itself in the moments of border crossing. Yet these moments are strategic places to observe the asymmetric relationships that are structuring elements of the Palestinian refugee experience.

In the Israeli-Palestinian context, Véronique Bontemps emphasizes the 'neverending bureaucratic procedures to obtain a permit, the countless obstacles to circulation and the hours in the checkpoints lines' that Palestinians have to undergo. All these procedures 'transform the waiting into a structured experience' (Bontemps, 2012).

It appears that there is room for a sociological and anthropological project that comparatively studies the social exchanges specific to the crossing of borders and social and cultural boundaries by migrants and refugees. Methodologically, this project could be achieved by closely following the social encounters, not only in the situations of transit, when migrants are 'on the road' to another country, but in different moments of passage at various scales of mobility. This paper attempts to explore the possibility of such a project and ranges as such on the experimental.

Describing their practices of mobility, Palestinian refugees in Lebanon emphasize situations of crossing over. Emerging from the folds of mobility, these situations happen at different scales of circulation (local and transnational). They concern passages (1) between distinct territories that involve police procedures such as checkpoints separating the camp and its surrounding spaces, police processes at the entrance in a foreign country and (2) between different social realms such as interaction with smugglers, with inhabitants of European cities, when they reach their 'Eldorado'. These passages involve an attempt at redefinition - partial and temporary - of the self, as well as individual and collective adjustments to the proposed social order.

Passages always create friction between awkward, strange, unfamiliar, threatening, or enjoyable universes and provoke an adaptation and transformation. They actualize different registers of identity: from the assigned identity at the checkpoint to situations where possibilities of self-representation are more open. 
In the foreign city, migrants experience a 'problematic access to the ways of life and the languages of the other' (Joseph, 1997, p. 136) ${ }^{4}$ that is characteristic to the urban mode of life. In all cases, crossings involve a transition, i.e. a passage which transforms, a passage from one nation-state to another, and moments of uncertainty related to the social interactions involving a range of attitudes from stigmatization to friendly reception. Transition is thus a generic category that regroups different social formulas of passage and crossing of borders and boundaries. It could be seen as the relational refraction of a global situation. Applied to the case of the migrants it sheds light on their precarious position in the world.

Transitions are bounded in time and space but they produce long-term effects on social life, on the perception and construction of otherness, ${ }^{5}$ and on the global experience of being a refugee and/or a migrant. Transitions nourish experiences of 'recognition', always with the risk of being assigned a specific identity: to be recognized as a stranger, an enemy, a member of a group whose legitimacy/legality is problematic for different reasons (recurrent tensions in Lebanon with Palestinians, racism, European migration legislation provoking a criminalization of migration, etc.). The relationship during these social exchanges becomes asymmetrical. Palestinians have to deal with potentially stigmatizing behaviour and/or a high degree of unpredictability of the situation due to the uncertainty of the meanings shared with the people they encounter - in Lebanon and in far-away cities. These boundaries create a distinction between lifestyles, collective habits, accents, languages, and appearances.

There, in a far-away city, they have to learn how to act in public space, to interact with different people, as well as officials they meet and must deal with. Therefore, their ability to evolve in different social worlds is an essential skill. It is an important element of their existential panoply and of the construction of their relationships to the world. Tactics of acknowledgement, calming down, humanization, affirmation of self, outside of or by the group, are also responses to the stigmatization expressed more or less euphemistically - and/or responses to the uncertainties of indifference. With their social competencies and mobilized resources, the individuals living these experiences are struggling to avoid finding themselves 'lost in transition'.

The social encounters occurring during the moment of passage are anthropological sites from which to observe how refugees experience their specific condition and how they react to it. The importance collectively given to these situations become apparent in the various narratives about the refugees' mobilities. My research while accompanying Palestinians, in particular those living in Nahr alBared camp in North Lebanon, 18 kilometres north of Tripoli, corroborates this. Since 2005, during intermittent fieldwork, including interviews, ${ }^{6}$ periods of residence in the camp since 2008, and a stay in Denmark in July 2012 with Palestinians from the camp, I recorded observations and collected narratives about experiences of passage. They form the ethnographic material I will mobilize here.

Focusing on inhabitants of Nahr al-Bared camp, this paper will describe experiences of transition ranging from the local to the transnational scale: at checkpoints (first part), along the uncertain roads of the illegal migration to Greece, 
through Syria and Turkey (second part), and in the big city, in Athens, where numerous young Palestinians arrive after going on these illegal trails (third part).

\section{Nahr al-Bared Checkpoint: Ordinary Control}

The Middle East is a fertile terrain for conducting studies of passages related to police/security and to the governmentality of spaces. This issue has been picked up especially by focusing on the Israeli-Palestinian conflict. The artist Sharif Waked with his work: 'Chic point' (fashion for Israeli checkpoints, 2003) produced the most impressive and emblematic vision of the prevalence of the checkpoint as a symbol of the regional order. It is a video of a fashion show with models wearing cloth showing their naked bellies, in reference to Israeli soldiers forcing people to prove that they are not wearing explosive belts. For a few years, scholars have been focusing on the Israeli checkpoint, emphasizing especially the temporal dimension of the passage. Véronique Bontemps (2012) underlines the confiscation (loss or investment) of time that the passage of the Allenby Bridge between the West Bank and Jordan implies. At Qalandiya checkpoint, Sylvaine Bulle (2008) describes how, despite 'the ordeals of the control, ... an intermediary social world at the border of the inside and the outside ... where specific forms of social and urban life are recreated' emerges. ${ }^{7}$.

\section{A Rap Song}

In 2006, Abdallah, a musician of the al-Karmel orchestra, ${ }^{8}$ wrote and recorded a rap song in a home studio in the camp. The song called hawajiz (checkpoints) is a criticism of the checkpoints that surround Naher al-Bared camp. It emphasizes the daily humiliation or at least the discomfort that checkpoints represent. Six years later, in 2012, the situation was considerably worse from the Palestinian point of view. The hawajiz were still there and controls had been reinforced as a result of the conflicts of previous years.

During three and a half months in 2007, the camp was at the centre of a battle between the Lebanese army and a jihadist group named Fatah al-Islam which had infiltrated the camp. The original camp, founded in 1949 and measuring one square kilometre, was completely destroyed and its extension (the 'new camp') partially destroyed. All the inhabitants were displaced and started coming back only at the end of October 2008. Following this event the Palestinian inhabitants of the camp had to obtain a permit from the military intelligence office in Tripoli to be able to enter the camp. In 2012 they still had to pass through one of the five checkpoints surrounding the camp. Their permits were checked, cars, luggage and bags were inspected. This situation further limited the fluidity of the passage and established a new configuration of control. With this a specific social moment emerged. It opened a new chapter in the thick book of the experience of the passage from one place/status to another.

In opposition to the military order that ruled the camp from 2007 the inhabitants of Nahr al-Bared camp demonstrated peacefully for 12 days in June 2012. The demonstration took place after the Lebanese army killed one of the shabab (young 
men) in the camp. He was protesting with others against the confiscation of the scooter of a man at one of the checkpoints for riding his scooter without the appropriate papers. The protest intensified during the funeral because the dead man had to be buried in a mass grave. The army prevented the opening of a new cemetery because it considers the designated area to be a military zone. The lack of space in the old one left the inhabitants with no choice but to bury the young man in a mass grave. The protest led to the death of another young man and left several wounded. In response inhabitants organized a sit-in at the centre of the camp to demonstrate for their rights.

These dramatic events highlighted the exasperation and the resentment the Palestinian inhabitants of Nahr Al-Bared feel towards the security procedures to which they are subjected. The denunciation of the behaviour of the army that led to the deaths of two young men targeted the military order that rules the camp. The first claim concentrated on one of the most disturbing manifestations of this order: the checkpoints. Eventually, the army authorities agreed to ease entry into the camp by abolishing the tasrih (authorization) required of every single inhabitant. Although checkpoints remain, individuals have 'only' to present their ID. Cars entering the camp along with luggage and bags are still inspected.

The narrative about, and observations of, the interactions between soldiers and inhabitants of Nahr el Barid provide a few snapshots of the passage through these points of control.

\section{Rhetoric of Humanity}

Five checkpoints control access to the camp. They are used by inhabitants according to different criteria: proximity to the destination in the camp, density of in- and outgoing traffic, and subjective individual criteria. For example, the passage at the small checkpoint of Al-Bayadé is supposed to be more 'relaxed' than other control points such as the larger and more frequented Mahamara or Al-Abde located on the Tripoli-Syria highway.

One day, I crossed the Al-Bayade checkpoint following an invitation to a wedding. On my way to the ceremony, I realized that my entry permit had expired and that I did not have time to renew it. Coincidentally, Hassan (an inhabitant of Bared) was in Tripoli and he offered to get me into the camp. He was betting that soldiers would not pay attention to the expiration date on my permit. On the way to the camp, Hassan did not show any signs of worry. In fact, he eventually won the bet and we entered the camp safely. We nevertheless spent a few tense minutes when the soldiers stopped us and concentrated on the different Arabic spelling of my name in my entry permit and car papers. Yet they did not see that the entry permit had expired and finally waved us through.

Hassan explained later that he feels close to the Lebanese army because his sister married a Lebanese soldier. Furthermore, Hassan's great-grandfather was Lebanese and had travelled to Palestine before 1948 to escape an arrest warrant. He returned to Lebanon after 1948 with the Palestinian refugees, and ever since has been one of them. The news of our successful crossing quickly spread among the wedding guests. The numerous enthusiastic comments it aroused sounded like a minor 
symbolic victory, and testify to the importance collectively given to the presence of these checkpoints. In general, they provoke feelings of anxiety, resentment and humiliation, and inhabitants experience their presence as discriminating.

Gharib (strangeness) is a recurrent notion mobilized to give meaning to the situation. It qualifies both what is strange/foreign, and what is unfamiliar: outside the common order and which is beyond belief. Most of the passages take place in daily routines; however, the situation of crossing a checkpoint is never anodyne. Every sign, even discreet, of disregard from a soldier is usually noticed, reflected upon and interpreted. The refugees define the moment of passage on a continuum between familiarity, which erases mediation, and strangeness that introduces uncertainty and doubt regarding the possibility of peaceful exchange with others.

The crossing of the checkpoint denies the refugees' yearning for normality. In this asymmetrical relationship soldiers can act disdainfully or adopt a more conciliatory attitude. Refugees adjust to the situation by modulating their responses. These range from questioning looks and astonishment, to the risky expression of their discontent, and even irony. Powerlessness is expressed through body language. Comments about the situation take place behind closed doors, when everyone has returned to their place, in the van, or the car. These comments appear as many little compensating acts allowing individuals to maintain or restore their dignity. The notion of strangeness appears in short dialogues: 'this soldier was strange' (gharib), for example, as an attempt to circumvent stigmatization.

These transitions reveal the stigmatization process by giving some tangible signs such as behaviours, looks, and words. The process provokes a cultural response. DJ Tamarrud (DJ Rebel) a young rapper of Nahr Al-Bared composed a song with the aim of symbolically restoring dignity to the refugee population: 'If you carry a blue ID, raise your head' (elli hâmel hawiyé zar'a rasu 'alê). ${ }^{9}$ The scene of an old man being harassed and ashamed of showing his refugee ID, the blue card that every refugee in Lebanon possesses, inspired these lyrics.

Refugees collectively accord great importance to the dignity of their passage. It depends on the behaviour of the one who holds 'legitimate force' at any checkpoint. Because the passage is a moment in which identity is assigned, the refugees invoke a meta-identity to restore some equality to their interaction with the solider. It could be summarized with the expression 'we are human beings like any other'. To generalize from this particular situation, the rhetoric of humanity is universally mobilized in situations of stigmatization.

Another snapshot offers an additional example of the way this rhetoric is mobilized. One day Sayyid, a young refugee, was stopped at a checkpoint in AlBayade and asked about his papers. While he was searching nervously for his papers in the car, the soldier commented in a conciliatory voice that he could take his time: 'It's not so important' (yalla basita). Sayyid referred to this comment to say that the soldier was 'humane' (insani). However, if Sayyid had not finally found his papers, he would have been denied access to the camp.

The recurrence of the notion of shared humanity is generally mobilized in a context of denial of elementary rights of refugees and migrants. Sylvain Perdigon (2008) noted the omnipresence of a 'vocabulary of inhumanity' (ghayr insân̂̂) in the 
conversations of shabab from Jal Al-Bahr gathering in Tyr, south Lebanon. The passage of the checkpoint brings this vocabulary because it actualizes the refugees' status and underlines their specific position at the margins of the world.

A lot of young Palestinians refugees seeking to build a decent live attempt to escape from their situation by travelling. A few of them obtain visas to western countries, either to complete their studies, or for a touristic stay - that they then overstay and often try to legalize at a later point in time. With no other options most young men have to travel clandestinely. Clandestine crossings to Europe are fraught with uncertainty but open the possibilities of a positive recognition and an 'access to' citizenship.

\section{Travel to Greece: Perilous Roads and Uncertain Crossings}

Travelling to Greece is a new kind of passage at a higher scale. Since the first years of the twenty-first century numerous young Palestinians from Nahr el-Bared have decided to try the risky and clandestine trip to the Greek coast. ${ }^{10}$ Notwithstanding the situation in Syria today, crossings are still undertaken. The young men hope to reach northern Europe, especially Scandinavia, where the Palestinian diaspora is large, and where they can count on relatives to help them upon their arrival. However, more often than not they are unable to travel beyond Athens, where they stay for varying periods of time, from six months to one year, and sometimes more. Then they, or at least some of them, return to the camp with a 'laisser-passer' from the Lebanese embassy in Athens. The return is usually a consequence of the difficulty in generating a livelihood in order to provide a decent life in the Greek capital. This city, which appears as a door to Europe, then turns into a prison that the shabab can escape only by returning to the camp.

During their journey to Greece, Palestinian refugees share with the migrants, as described by Streiff-Feynard and Segatti (2011, p. xiv) in accordance with Turner, a situation of liminality, that is to say: a situation 'in which individuals caught for a time between two states (as migrant on the road and as immigrant, the state to which they aspire) experience the typically ambiguous situations characteristic of threshold people'. From the travel narratives I collected, I will identify some 'categories that migrants use to make sense of their mobility and to ascribe meaning to their action' (Streiff-Feynard \& Segatti, 2011, p. xvi), by focusing on the relational events occurring 'on the road'.

\section{Noah's Arks of Precarity}

Many 'roads' lead to Europe, and new roads are created and old ones closed. Most of the time, the new destination is a country that the (potential) immigrant can reach with a tourist (or a business) visa. From there s/he will try to cross into western Europe. The trip to Greece does not require a visa, or a plane ticket. ${ }^{11}$ It is an overland and then maritime migration, the cost of which is highly variable. It depends on the time spent in Turkey waiting for a boat and costs between $\$ 1,000$ and $\$ 4,000$. The highest price to pay might very well be on the perilous way through 
war-torn Syria, though this disorder in some ways facilitates a migrant's movement through the country.

The descriptions of these clandestine trips superpose images of threatening landscapes (the mountains between Syria and Turkey and the sea between Turkey and the Greek islands) with a disparate humanity composed of other migrants of diverse origins, smugglers, policemen and border guards. The Palestinian migrants experience a temporary society. A society formed with those excluded from officially sanctioned mobility, who displace clandestinely, often at night, and travel on precarious Noah's Arks that sail different parts of the Mediterranean.

Najdé, a young man from Nahr Al-Bared, gives an impressive description:

We arrived at the debarkation point [to Greece]. A long stretch of 100 meters sloped to the sea, through a mountain, cut by a deep valley. When we arrived at the sea, I got goosebumps seeing about a hundred people of all ages, and all categories, women, elderly, young people, Egyptians, Palestinians, Somalis, Bangladeshis. We were two groups leaving for Greece. During the wait we started chatting. The smuggler, impatient, got in contact with the boat that was running late. Then the big boat came towards us and anchored about 100 to 150 metres from the beach. We installed an inflatable passageway to get from the beach to the ship. Four other young men, three Egyptians and I helped the little ones and the women traverse.

In this context, the presence of illegal migrants of various origins provokes minimalist sociabilities where national stereotypes are used as a way to ease the interaction. Najdé gives an example of this use of stereotypes as a mutual way of recognition in a tense exchange. He describes meeting a smuggler on the island by accident. The man had threatened him with a knife when he refused to sit down in the bottom of the boat because he was afraid of dying in a shipwreck. ${ }^{12}$

The Kurdish guy came close to me and I stuck a branch from a tree to his neck and told him: Who do you think you are threatening with your knife? Don't you know who we are? You never heard what they say about Palestinians? I swear, I can reduce you to bits right here. Wasn't that what you wanted, to massacre me? He answered that he was sorry and that his intention was to reach the destination and that he didn't want to hurt me.

\section{Of Cows and Men}

Najdé presents his narrative as an epic when he describes the mountains and the sea.

The beach was immense with fascinating rocks that frighten you. We came off the ship that moored near the beach so as not to run aground. They made us go down into the water. I lifted my jacket onto my head but kept my cloth on. I walked to the beach, the water was up to my knees. We carried the children one 
by one, we helped the women by holding their hands, and we all disembarked. Once arrived on the island, we separated and everybody went their own way. The Somalis went to one side, the Bangladeshis to another, and we Palestinians took still another way accompanied by a Turk that escaped with us to Greece.

Despite these dramatic descriptions, he keeps a sense of humour in his descriptions of the border crossing accompanied by cows that the smuggler try make cross the borders between Syria to Turkey on the same voyage as the migrants.

The cows were fleeing with us [ . . ] we stopped somewhere to rest. Instead of reassuring us and keeping up our morale, the smuggler made the situation even more insufferable by telling us about his misadventure at this spot: 'One time I came through here with some clandestine travellers and we were shot at.' We were on the verge of a nervous breakdown. We asked him why he was telling us such a story: 'Instead of reassuring us, you tell us that you were shot at here? Why do you scare us?'

He answered: 'it is not that I want to scare you, but I am telling you the truth'. I told him: 'Let's hope all will be well. And that God will be with us. Let's move'. So we went on. A man came to meet us. He talked to us and took us to the border. It was one of the smugglers. He had a Kalachnikov and a pair of pliers. We arrived exactly at the level of the metal fence. He cut it. We passed through one by one onto a road in the border zone. We crossed the border zone on the double and started running down a good stretch of land. We ran, ran, ran and by nightfall we arrived at a house. The cows accompanied us, obviously. We put them in the ground floor and we, four young guys, slept in the barn. We slept on hay-ricks and we covered ourselves because it was snowing in abundance and it was very cold.

The last step of the adventure is the sea crossing, and the arrival on one of the islands (Samos, Lesbos, Chios or Rhodes). Here the passage often ends with an arrest when the migrants land.

At this point some Palestinian refugees still hope that they will enjoy privileged treatment from the Greek authorities. But they are subject to the same treatment as others foreign nationals. Baha, like most of his compatriots, thinks that the image of Palestinians changed because of the other Arabs that represent themselves as Palestinian hoping to benefit from the sympathy Greek people are supposed to have with the cause. ${ }^{13}$

They loved Palestinians a lot, a lot, a lot, but what happened ... Greeks love Palestinians and Yasser Arafat, the police, all people respected us. But this last six-seven years, when for example the Algerian was making trouble with the Egyptian, shouting that he will kill him, the Syrian who was selling drugs; when they were arrested, they pretended that they were Palestinians; that was helping them. 
The decision to travel is rooted in a moral claim. Moreover, refugees bring forward an ethics of mobility when they consider their experience of migration. It is their duty to travel to pursue a better life for themselves and theirs and it is their right to go from one place to another that they juxtapose to the criminalization of their migration. One of the gains they hope to obtain is a nationality that will allow them to benefit from a citizenship. The search for a nationality is thus a recurrent item of 'travel narratives'. In this sense it corresponds to the notion of 'visée ethique' brought forward by Paul Ricœur (1990, p. 202) as "the aim for the "good life" with and for others in just institutions'.

I travelled because I am an educated person; I have the ambition for a better future. But I live in Lebanon, why can I not live like the people here, like any Lebanese? Why? Why would my son become a terrorist, and not a doctor? [referring to Nahr al-Bared Events and the accusation of terrorism against all Palestinian by a part of the Lebanese public opinion] [ . . . ] I just want for my son to have a future, for him to have a nationality.'

The journey inevitably ends with a stay in one of the Greek detention centres that have been set up all over the islands. Finally, after a detention period that varies. the migrants are released with a temporary residency permit.

\section{Ordeals in the Faraway City: The Racist, the Trickster and the Lovers}

Waiting to depart, the conversations of the young men in the camp revolve around the trip and integration in Europe. The clandestine voyage is discussed. Everybody knows that Europe changes you and sometimes even destroys you. This voyage is an object of controversy, but migration in all its forms, legal and illegal, remains on the horizon of the great majority of the last generation of refugees. The stories of the experiences of the young men who tried their luck fuel the debates about integration in European countries that the youth have in the cafes. Their reading of current affairs, the echoes that reach them regularly through members of the diaspora, lead them to think that not all is idyllic over there. Discussions revolve around integration in public space insofar as there is an unvoiced worry about the reception and view of Arabs and especially Muslims in Europe. Suspicions of racism and lack of understanding are circulating in the camp, inspired especially by the controversy about the Islamic veil in Europe ${ }^{14}$ (most pronounced in France and Germany).

\section{Khalil}

Khalil left because of the (perceived) difficulty to find a place in the European public space. He cites reasons of morality rooted in religion. Whether these explanations mask a failure to gain a foothold or whether it attests to a real taking into account of an insurmountable difference, they are fundamental to his narrative about his experience of Greek public space. 
My first encounter with Khalil happened in his little workshop just behind the camp on the main road leading to the Syrian border. It was a very rainy day, the kind of deluge that regularly floods the country during winter. Contrary to the majority who complain about it, Khalil was delighted by the climatic event. It promised work, because lightning regularly burns out television sets, which he then gets to repair in his little workshop. He had recently taken up his old occupation after returning to Nahr al-Bared from a one-year stay in Greece.

Immediately after I sat down, Khalil invited me to visit him in the camp. He wanted to share his everyday basic tasks with me, at home where most of his energy is devoted to education of the children, household duties, working in the workshop, and simple leisure time like fishing, the foundation of his daily life. In fact, it is this ordinary set of daily activities that gives him a feeling of 'ontological security' (Giddens, 1991).

Like Khalil, when Palestinian migrants return to their home, they enter the temporality of the camp. This is shown, practically and even symbolically, by their first important act: 'opening a house' (fatah beyt) - that means getting married and having children and settling in a proper home. By immersing themselves in their daily routines, Palestinians coming from Athens try to repair their life after the suffering of the passage and the difficulties of daily life in Athens.

I left. We went to Turkey. Myself, I had money before, I had a lot of money, I just went for my son to have a future, for him to have a nationality. When I went, I saw. I changed a lot, because I am a Muslim and because of the cultural differences. But the Greek people are good, they love the Palestinians so much. Once they knew I was a Palestinian, they would say 'fuck America, fuck Israel'.

Khalil decided to go back to Lebanon after he witnessed what he perceived as a disturbing scene on the Athens subway. One day, in full view, a young couple, a girl and a boy, were flirting quite uninhibitedly, the boy lifted up the girl's skirt and stroked her buttock shamelessly. Khalil describes the situation as a moral shock that made him uncomfortable in Greek public space. This scene hastened his decision to return to Lebanon. In spite of the fact that he was one of the few Palestinians in Athens enjoying a decent and economically stable life. As a skilled electrician, he made himself indispensable at a local electronics shop. But unlike other shabab, Khalil was already married with kids when he embarked on his Greek adventure.

As he explains:

At this moment I began to think about going back, there is a lot of freedom in Europe, there are no limits. I was living comfortably, but the culture is so different. How could my wife and daughter be exposed to something like this. It's a big problem for us, in Islam; we will not be able to handle this. 
The vision of public space as too permissive constitutes one of the categories of the social unease that leads to the difficulty of dealing with the foreign city. But it is more generally the European city that instils a fear of moral dissolution and loss of value, especially in relation to children, where the temptation of drugs looms above all else. In contrast, the camp is perceived as a place where community values are still intact and held in high esteem. Partially because of this conception some fathers send their sons to the camp during summer vacation hoping that they will acquire some of their community's values.

\section{Nizzar}

Nizzar had another experience in Greece. If Khalil encountered the lovers, he met the trickster and the racist. Nizzar, who spent seven years in Greece, played the role of go-between for his compatriots, the refugees from the camp. He likes to say that his flat in Athens was a Nahr Al-Bared embassy in Greece. His knowledge of the Greek idiom, and his relatively good integration allowed him to play this role.

As a testimony of his integration, he shows pictures of his participation in the demonstrations during the political and social uprising in Greece in 2008. He shows a picture where he can be seen posing proudly with a Palestinian flag surrounded by both Palestinians and Greeks.

Despite his long experience in Greece, Nizzar explains, he had been duped out of $€ 2,000$ by his employer after having worked for him for years. What made the experience even worse was the fact he was unable to defend himself. It was impossible to file a complaint with the police because his application for a renewal of his residency permit was rejected.

Moreover, he already had unpleasant encounters with the Athens police, as he remembers:

There are very racist Greeks and others who don't have problems with foreigners. But some of them are very racist. They ask: 'What are you doing in my country?' It happened to me several times [ . . . ] And let me tell you that the Greek people are very racist. I spend 7 years and I noticed this. They like you just when they can profit from you. Let me give you an example: once a policemen arrested me. He asked me: 'what are you doing here? What are you doing here in Greece?' He insulted me. I told him my house is here, I'm just going back to my house. I live here.

- Why are you living here ?

- I come from Palestine - So get back there. - I told him, I can't because there are problems there. He told me go to Bulgaria, to Romania, to Italy. - So I told him if you tell me how I can get there I will give you money because I'm not happy at all in your country. Then he became mad and he turned it into a nationalist issue .... 
So he called his colleagues and told them that I attempted to attack him. But when they arrived they laughed at him. It was summer time and I was wearing a pair of shorts and a light shirt. They laughed because I'm so skinny. They told him this guy attacked you!!

But because of this guy, I spend hours at the police station. There he said that I was Pakistani without papers but I can understand Greek and I said that I was Palestinian and I had all my papers.

Like many others, Nizzar finally returned to the camp, with his Japanese wife and her child. He met them on the boat going to Greece after he had been rejected at the Italian border (he didn't even disembark from the boat). Now, he is stuck in Lebanon waiting for a travel document that would allow him to travel to Japan with his wife and her child.

All the migrants, after their return to the camp, tell of the impossibility to live decently in Athens. After fruitless attempts to find a regular job; one of the few choices they have is dealing drug, and other undertakings that involve breaking the law, or going back to the camp. At the beginning, they perceive the city to be a place of playful but careful exploration. Soon after, they realize the precarious situation in which they find themselves. After the hope of urban exploration come difficult times and social isolation.

Unlike the Bangladeshi community which has its own associations, shops and gathering places in Omonia, Palestinian migrants do not have the benefit of a wellintegrated community on which they could rely (Noussia \& Lyons, 2009).

Najde shows this isolation very well when describing his arrival in Athens:

We arrived at six in the morning. I searched and searched. There was nobody there. Everybody was gone. We stayed, the Fulan brothers and myself. We explored the place and asked around. We didn't find anybody that could understand us. When we addressed people in English they answered in Greek. That is how racist they are. Then, I swear, I saw a guy with a semi bald head some 300 meters away from me. I rushed towards him and greeted him. He answered in Arabic: 'wa alaikum assalam'. I asked him if he was Arab. He said yes. I explained that I was looking for a place where a lot of Arabs live. Where is this place? He was Egyptian. He showed me how to go there: you go to the subway, you buy a ticket for one euro and you take the subway. He explained what I needed to do: you get on the train and you get to the first region. You get off on the second station after hearing the word Omonia.

The numerous returns to Nahr el Bared are proof of the impossibility of living in Athens or getting to another European country. All the narratives insist on the difficulty of finding a place in the foreign city. The migrant is not in this case the emblematic cosmopolitan human being that Park and Simmel have seen in him. $\mathrm{He}$ is rather the marginal man, unsteady and maladjusted as more pessimistically 
described by Stonequist (see Cuche, 2009). Here the migrant appears as 'a transitory human being, hesitant in the passing through social worlds, painfully conquering social ties the trust of the host society' (Bulle, 2012, pp. 229-230).

\section{Conclusion}

The refugees' narratives depict encounters as particular moments of asymmetric social exchanges taking place during transitional phases. They emphasize the relational dimension of the passage while describing their mobility. The ambivalent categories they deploy to interpret their experiences compensate for the asymmetric position and make sense of these situations.

The notion of strangeness (gharib) is such an ambivalent category. Strangeness is recurrently used by Palestinians to describe their situation. Didier Lapyeronie (2008, p. 17) notes 'the strong feeling of strangeness towards the social' of the inhabitants of the ghetto. As if 'the dominant norms invalidated their own reality permanently'. At checkpoints, the social exchanges always occur under the threat of being assigned an identity, and being stigmatized. It is not the refugee that gets to define himself in this situation, but he finds himself in a process where individual and collective attributes are assigned by an external actor.

Yet here the notion of strangeness, not as an analytical category but as mobilized by people, answers to and compensates for this reduction and loss of individual and collective possibilities to act in the world. It gives a language to deal with uncertainty and circumvent stigmatization. This notion euphemizes a difficult and potentially hostile situation in the refugees' daily routines, it displaces the power relationship into the realm of the unfamiliar. It offers one way to deal with and to find closure for the offence suffered.

On a different scale, even if they do not succeed in their migratory project, they perceive that they were about to penetrate another political regime giving them social and political rights. The word 'welcome' is recurrently used in the narratives of the arrival in Greece. The emphasis given to this word coming from the mouths of policemen testifies to the importance they give to the most modest sign of a recognition. Even if the first encounter with Greek authorities invariably ends by a stay in a detention centre, refugees aim to show that they can already feel that something has changed in the way they are treated by authorities.

The attitude of Greeks as experienced by Khalil, who was not abused, but on the contrary was greeted with a residence permit when he landed in Greece, provokes a comment on the humanity of the officers who found and welcomed him and his companions on this Greek Island:

We landed on a beach and over there the police were already waiting for us, they took us and we were interviewed. Of course, there was a lawyer and there was also a journalist who helped us a lot. The police did nothing to us because the journalist was present to take photos. We talked, and talked. The police knew all about us, the three Palestinians. They told us: 'You come from Lebanon', they knew everything: what time we left, what time we bought the 
plane ticket what time and we arrived at the airport in Istanbul . . And finally, after we said all that, they told us: welcome anyway.

Isaac Joseph distinguishes two kinds of hospitality: 'the face-to face interaction with the stranger' and the hospitable quality of the city where the hierarchical relationship has been overcome and is replaced by a common grammar of interaction based on the equality between anonymous individuals (Joseph, 1997, p. 130). This 'welcome' is the manifestation of the hospitality due to the stranger and offers the longed-for recognition. Yet it also expresses that they were never able to access 'the modes of auto-regulation of a common world' (ibid., p. 132).

Those who returned to the camp were not given the possibility to adjust themselves to the new habits, mentalities or behaviours. Consequently, the attempt to secure a foothold in Europe failed. Most of the time, Palestinian shabab encountered local figures such as the lovers, the soldier, the racist, the trickster, the policeman and, of course, the trafficker or the smuggler. They very rarely get the possibility to share a common world and experience with Greek citizens that would put them on an equal footing, at least temporarily. Generally, they enter into these interactions with their identities and their position already assigned to them.

The experience of the asymmetrical relationship is common to the different kinds and scales of transition: from the checkpoint to the relationship with the smuggler, the state of precariousness shared with other migrants, and the encounters with the European citizens and authorities. An anthropology of transitions provides an analytical framework to reveal the ways that global political structures refract in the smallest scale of human activity and influence the relational dimension taking place during passages.

Furthermore, this anthropology sheds light on these moments of social exchanges where, despite their social skills, competencies and resources, migrants and refugees find themselves 'lost in transition'.

\section{Notes}

1. The disaster: the term designates the creation of the Israeli state in 1948 and the exile of more than 700,000 Palestinians from Palestine to neighbouring countries, 100,000 have settled in Lebanon.

2. Most of these studies are works in progress in order to achieve a $\mathrm{PhD}$. For a list of refugee related research projects and doctoral dissertation research: http://prrn.mcgill.ca/research/. See also Latif, 2008 (for Burj al-Barajné camp).

3. Also see Abu Zaki, oral intervention at CEMAM, St Joseph University, Beirut, 1 June 2011.

4. 'Le phénomène urbain comme mode de vie, c'est précisément cet accès problématique aux modes de vie et aux langages de l'autre'.

5. How one perceives and outlines an image of the other: citizens, Lebanese or European citizen, military personnel, policeman, smuggler, other Arabs, etc.

6. To document this specific topic I conducted 21 interviews with Palestinian refugees who came back to the camp after they had travelled in Greece. I choose from these most representative narratives in order to provide ethnographic material for this study.

7. 'Il [the checkpoint] révèle un monde social intermédiaire à la frontière du dehors et du dedans, ... , où se recréent des formes spécifiques de vie sociale et urbaine.' 
8. It is affiliated to the Popular Front for the Liberation of Palestine and performs nationalist and traditional Palestinian music.

9. The strong symbolism of this ID leads a rap crew in Ayn al-Héloué to write a song entitled 'hawiyé Zar'a': 'Blue ID my name is refugee, what is your nationality? Palestinian! You lost it, you forgot it!' (Puig, 2006).

10. There are many roads leading to Occidental countries, in summer 2012 some shebab tried a new road by heading to a country in East Europe by plane with a tourist visa, then trying to pass into west Europe.

11. According to FRONTEX (the European Agency for the Management of Operational Cooperation at the External Borders of the Member States of the European Union established in 2004), 80 per cent of illegal entrants to Europe transit via Greece. It has remained a target entry point for irregular migration. In total 87 per cent of detected illegal border crossings to the EU during 2010 occurred on the border of Greece in the Eastern Mediterranean or Albania-Greece irregular migration routes.

12. Nobody forgot in Nahr al-Bared the death of two brothers after the shipwreck of their boat between Turkey and Greece.

13. The Palestinian cause: the national struggle for the creation of the state.

14. Regarding this topic Europe is viewed as one coherent entity where Islamic values are attacked.

\section{References}

Bontemps, V. (2012) Le temps de traverser le pont. Pratiques et perceptions des temporalités dans les Territoires palestiniens occupés, Temporalités, 'Fragments temporels du monde arabe' 15, Available at http://temporalites.revues.org/1995\#ftn5 (accessed 25 November 2012).

Bulle, S. (2008) Une urbanite dans l'épreuve: le mur de separation à Jérusalem et ses bordures. Eléments pour une analyse des actions situées en milieu problématique, Asylon, 'Palestiniens en/hors camps, Formes sociales, pratiques des interstices', 5, Available at http://www.reseau-terra.eu/article801. html (accessed 25 November 2012).

Bulle, S. (2012) Venir à la présence du monde. L'horizon de la migration comme expérience de soi et comme plan de vie, in: K. Doraï \& N. Puig (Eds) L'urbanité des marges. Migrants et réfugiés dans les villes du Proche-Orient (Paris: Téraèdre Éditions, IFPO), pp. 229-236.

Cuche, D. (2009) 'L'homme marginal': une tradition conceptuelle à revisiter pour penser l'individu en diaspora, Revue européenne des migrations internationales, 3, pp. 13-31.

Giddens, A. (1991) Modernity and Self-Identity. Self and Society in the Late Modern Age (Cambridge: Polity Press).

Joseph, I. (1997) L’hospitalité: prises, réserves, épreuves, Communications, 65, pp. 131-142.

Lapyeronie, D. (2008) Ghetto urbain, Ségrégation, violence, pauvreté en France aujourd'hui (Paris: Robert Laffont).

Latif, N. (2008) Space, power and identity in a Palestinian refugee camp, Asylon, 5, Available at http:// www.reseau-terra.eu/article800.html (accessed 25 November 2012).

Noussia, A. \& M. Lyons (2009) Inhabiting spaces of liminality: migrants in Omonia, Athens, Journal of Ethnic and Migration Studies, 4, pp. 601-624.

Perdigon, S. (2008) La corniche des célibataires L'intimité à l'épreuve du transnationalisme chez les jeunes Palestiniens de Jal al-Baher, Liban-Sud, Les Cahiers de l'IFPO. Available at: http://books. openedition.org/ifpo/450 (accessed 4 September 2011).

Perdigon, S. (2010) The one still surviving and viable institution, in: A. Knudsen \& S. Hanafi (Eds) Palestinian Refugees: Identity, Space and Place in the Levant, Routledge Studies on the Arab-Israeli Conflict (London: Routledge), pp. 165-179.

Peteet, J. (2005) Landscape of Hope and Despair: Palestinian Refugee Camps (Philadelphia: University of Pennsylvania Press).

Puig, N. (2010) Welcome to the camps. The emergence of Palestinian rap in Lebanon: a new social and political song, in: M.A. Khalidi (Ed.) Manifestations of Identity, The Lived Reality of Palestinian Refugees in Lebanon (Beirut: Institute for Palestine Studies, IFPO), pp. 109-124. 
Ricoeur, P. (1990) Soi-même comme un autre (Paris: Seuil).

Sayigh, R. (1979) Palestinians: From Peasants to Revolutionaries: A People's History (London: Zed Books).

Sayigh, R. (1994) Too Many Enemies: The Palestinian Experience in Lebanon (London: Zed Books).

Sayigh, R. (2006) Palestinians: from peasants to revolutionaries a quarter of a century on. Unexplored problems of Palestinian identity, in: Temps et espaces en Palestine. Flux et résistances identitaires (Beyrouth: IFPO), pp. 247-257.

Sfeir, J. (2008) L'exil palestinien au Liban. Le temps des origines (1947-1952) (Paris: Karthala-IFPO).

Streiff-Fénart, J. \& Segatti, A. (Eds) (2011) The Challenge of the Threshold. Border Closures and Migration Movements in Africa (Lanham, MD: Lexington Books). 